\title{
Metabolism and root exudation of organic acid anions under aluminium stress
}

\author{
Eduardo D. Mariano1, Renato A. Jorge ${ }^{2}$, Willem G. Keltjens ${ }^{3}$ and Marcelo Menossi ${ }^{1,4 *}$ \\ ${ }^{1}$ Centro de Biologia Molecular e Engenharia Genética, Universidade Estadual de Campinas, CP 6010, 13083-875 Campinas, SP, Brazil; 2 \\ Departamento de Físico-Química, Instituto de Química, Universidade Estadual de Campinas, 13083-970, Campinas, SP, Brazil; ${ }^{3}$ Department \\ of Soil Quality, Environmental Sciences, Wageningen University, P.O. Box 8005, 6700 EC, Wageningen, The Netherlands, ${ }^{4}$ Departamento de \\ Genética e Evolução, Instituto de Biologia, Universidade Estadual de Campinas, 13083-875, Campinas, SP, Brazil. *Corresponding author: \\ menossi@unicamp.br
}

Numerous plant species can release organic acid anions $(\mathrm{OA})$ from their roots in response to toxic aluminium $(\mathrm{Al})$ ions present in the rooting medium. Hypothetically OA complex $\mathrm{Al}$ in the root apoplast and/or rhizosphere and thus avoid its interaction with root cellular components and its entry in the root symplast. Two temporal patterns of root OA exudation are observed. In pattern I, OA release is rapidly activated after the contact of the root with $\mathrm{Al}$ ions while in pattern II there is a lag phase between the addition of $\mathrm{Al}$ and the beginning of OA release. Compounds other than OA have been detected in root exudates and are also correlated with $\mathrm{Al}$ resistance in plants. Plant species like buckwheat and tea show mechanisms of Al tolerance, which confer them the capacity to inactivate and store $\mathrm{Al}$ internally in the leaves. Disturbances in metabolic pathways induced by $\mathrm{Al}$ are still obscure and their relation to the altered OA concentration observed in roots under Al stress is not yet established. High concentrations of OA in roots do not always lead to high rates of OA release even when the spatial distribution of these two characteristics along the root axis is taken into account. Al induces high permeability to OA in young root cells and anion channels located in the cell membrane have been proposed to mediate the transport of OA to outside the cell. Genetically modified plants that overexpress genes involved in the biosynthesis and transport of OA as well as in Al toxicity events at the cell level have been generated. In most cases the transformations resulted in an improved ability of the plant to cope with Al stress. These promising findings reinforce the possibility of engineering plants with superior resistance to Al-toxic acid soils. The environmental impact of the large amounts of root exudates possibly conferred by these genetically modified plants is discussed, with special emphasis on soil microbiota.

Key words: $\mathrm{Al}$ resistance, $\mathrm{Al}$ toxicity, anion channels, root exudates, transgenic plants.

\begin{abstract}
Metabolismo e exsudação de ânions de ácidos orgânicos sob estresse de alumínio: Várias espécies vegetais liberam ânions de ácidos orgânicos (AO) de suas raízes em resposta a íons tóxicos de alumínio (Al) presentes no ambiente radicular. Hipoteticamente esses AO complexam os íons de Al presentes no apoplasto da raiz e/ou na rizosfera evitando assim sua interação com componentes celulares e ainda sua penetração no simplasto da raiz. Dois padrões temporais de exsudação são reconhecidos. No padrão I, os AO são rapidamente liberados pelas raízes após a exposição das mesmas aos íons de Al. No padrão II de exsudação, ocorre um atraso na liberação de $\mathrm{AO}$ após exposição das raízes à solução contendo $\mathrm{Al}$. Outros compostos além dos $\mathrm{AO}$ foram detectados em exsudatos radiculares e relacionados com mecanismos de resistência a $\mathrm{Al}$ em plantas. Espécies vegetais como trigo sarraceno e chá apresentam mecanismos de tolerância ao $\mathrm{Al}$. Estes mecanismos conferem às plantas capacidade de inativar e de armazenar o $\mathrm{Al}$ em formas não tóxicas nas folhas. Os distúrbios induzidos por $\mathrm{Al}$ em rotas metabólicas ainda são desconhecidos, assim como a relação desses distúrbios com as mudanças nas concentrações de $\mathrm{AO}$ em raízes que estão sob estresse de Al. Altas concentrações internas de $\mathrm{AO}$ nas raízes nem sempre levam a altas taxas de exsudação desses compostos, mesmo quando a variabilidade espacial da concentração e da exsudação ao longo do eixo radicular é considerada. Certamente $\mathrm{Al}$ induz uma grande permeabilidade de $\mathrm{AO}$ em células jovens da raiz. Canais aniônicos localizados na membrana plasmática são os prováveis transportadores desses compostos orgânicos para fora da célula. Plantas que superexpressam genes envolvidos na síntese e na exsudação de AO bem como genes relacionados com a toxidez de $\mathrm{Al}$ foram desenvolvidas pela engenharia genética. Na maioria dos casos essas plantas tiveram uma maior capacidade para desenvolver sob estresse de Al. Esses resultados indicam, portanto, novas alternativas para o desenvolvimento de plantas mais adaptadas às condições de solos ácidos e com problemas de toxidez de Al. O impacto ambiental que a grande quantidade de exsudatos radiculares de plantas geneticamente modificadas pode causar, especialmente na microbiota do solo, é discutido.
\end{abstract}

Palavras-chave: canais aniônicos, exsudatos radiculares, plantas transgênicas, resistência a Al, toxidez de Al. 


\section{INTRODUCTION}

Organic acids of low molecular weight have often been mentioned as playing an important role in certain mechanisms evolved by plants to cope with environmental stresses like aluminium (Al) toxicity, and phosphorus (P) and iron (Fe) deficiency (Jones, 1998; Ryan et al., 2001; Kochian et al., 2004). These organic acids are carbon compounds with at least one carboxyl group $(-\mathrm{COOH})$, and play a fundamental role in cellular metabolism. Some of them are involved in energy production as intermediates in the tricarboxylic acid (TCA) cycle (e.g. citrate, malate), while others are directly or indirectly involved in many other metabolic processes including the assimilation of carbon and nitrogen, the regulation of cellular $\mathrm{pH}$ and osmotic potential, the maintenance of electroneutrality during excess nutrient cation uptake, and the supply of energy to symbiotic bacteria (e.g. malate, malonate, oxalate) (Haynes, 1990; Marschner, 1995; Taiz and Zeiger, 2002). At the near-neutral pH of the cytosol, most of these acids exist there as fully dissociated anions (Taiz and Zeiger, 2002) and are almost certainly released from roots as such (Ryan et al., 2001).

Several plant species are able to release organic acid anions (OA) from their roots in response to toxic $\mathrm{Al}$ species present in the rooting medium while others release these compounds when growing under a deficient supply of $\mathrm{P}$. Because OA can carry a varying negative charge, they can form complexes with $\mathrm{Al}$ thereby reducing its activity in solution and toxicity to roots (Delhaize and Ryan, 1995; Jones, 1998). Mechanisms that prevent Al from crossing the plasma membrane, entering the symplast, and reaching sensitive intracellular sites (Al exclusion) are mechanisms of $\mathrm{Al}$ resistance while those conferring the ability of plants to tolerate $\mathrm{Al}$ in the root (and/or shoot) symplast (internal resistance) are mechanisms of Al tolerance (Taylor, 1991; Kochian, 1995).

The processes leading to root $\mathrm{OA}$ exudation under Al stress are not yet fully understood. The biochemistry, physiology, and genetic basis of the mechanisms that may confer on root cells a higher capacity to produce and export these metal ligands out to the root apoplast and rhizosphere, are beginning to be understood and will be the main focus of this review.

\section{Effect of Al on root exudation of $\mathrm{OA}$ by plants}

It is well documented that numerous plant species can resist $\mathrm{Al}$ through $\mathrm{OA}$ exudation, with malate, citrate, and oxalate being the main OA released (Table 1). Two temporal
Table 1. Plant species with Al-induced OA release by roots

\begin{tabular}{|c|c|c|}
\hline Plant species & $\begin{array}{l}\text { Main OA } \\
\text { exuded }\end{array}$ & Reference $^{\mathrm{a}}$ \\
\hline Arabidopsis (Arabidopsis thaliana L.) & citrate & (16) \\
\hline Barley (Hordeum vulgare L.) & citrate & $(26)$ \\
\hline $\begin{array}{l}\text { Buckwheat (Fagopyrum esculentum } \\
\text { Moench) }\end{array}$ & oxalate & $(22,27,28)$ \\
\hline \multirow[t]{3}{*}{ Maize (Zea mays L.) } & citrate & $(8,9,11,12,13)$ \\
\hline & $\begin{array}{l}\text { citrate and } \\
\text { malate }\end{array}$ & $(10,15)$ \\
\hline & oxalate & (14) \\
\hline Oat (Avena sativa L.) & citrate & $(22)$ \\
\hline Oilseed rape (Brassica napus L.) & $\begin{array}{l}\text { citrate and } \\
\text { malate }\end{array}$ & $(22)$ \\
\hline Radish (Raphanus sativus L.) & citrate & $(22)$ \\
\hline Rice (Oriza sativa L.) & citrate & $(21)$ \\
\hline Rye (Secale cereale L.) & $\begin{array}{l}\text { citrate and } \\
\text { malate }\end{array}$ & (6) \\
\hline Sickle senna (Cassia tora L.) & citrate & $(18)$ \\
\hline Snapbean (Phaseolus vulgaris L.) & citrate & (29) \\
\hline Soybean (Glycine max L. Merr) & citrate & $(19,20)$ \\
\hline Sunflower (Helianthus annuus L.) & malate & (24) \\
\hline Taro (Colocasia esculenta L.) & oxalate & $(25)$ \\
\hline Tobacco (Nicotiana tabacum L.) & citrate & (17) \\
\hline Triticale (Triticale hexaploide Lart) & $\begin{array}{l}\text { citrate and } \\
\text { malate }\end{array}$ & $(23)$ \\
\hline Wheat (Triticum aestivum L.) & malate & $(1,2,3,4,5,6,7)$ \\
\hline
\end{tabular}

a 1. Delhaize et al. (1993); 2. Basu et al. (1994); 3 Pellet et al. (1996); 4 Cocker et al. (1998); 5. Andrade et al. (1997); 6. Li et al. (2000); 7. Zhang et al. (2001); 8. Pellet et al. (1995); 9. Jorge and Arruda (1997); 10. Kollmeier et al. (2001); 11. Piñeros et al. (2002); 12. Mariano and Keltjens (2003); 13. Jorge et al. (2001); 14. Kidd et al. (2001); 15. Wang et al. (2004); 16. Hoekenga et al. (2003); 17. Delhaize et al. (2001); 18. Ma et al. (1997b); 19. Yang et al. (2000); 20. Silva et al. (2001); 21. Ma et al. (2002); 22. Zheng et al. (1998a); 23. Ma et al. (2000); 24. Saber et al. (1999); 25. Ma and Miyasaka (1998); 26. Zhao et al. (2003); 27. Zheng et al. (1998b); 28. Ma et al. (1997a); 29. Miyasaka et al. (1991).

patterns of OA exudation have been observed in Al-resistant plants (Ma, 2000; Ma et al., 2001). In pattern I, observed in wheat (Delhaize et al., 1993), buckwheat (Zheng et al., 1998b) and barley (Zhao et al., 2003), OA release is rapidly activated (15 to $30 \mathrm{~min}$ ) after exposure of the plants to $\mathrm{Al}^{3+}$ solution, and the rate of release remains constant with time. This pattern suggests that $\mathrm{Al}^{3+}$ ions activate an existing mechanism of OA transport in the plasma membrane and therefore the activation of genes is not necessary. In pattern II, observed in Cassia tora (Ma et al., 1997b), rye (Li et al., 2000) and triticale (Ma et al., 2000), there is an evident delay in the onset of OA release after the addition of the $\mathrm{Al}^{3+}$ solution. Furthermore, contrary to pattern I, in pattern II the rates of OA release increase with time. In C. tora and rye the 
rate of Al-induced OA release was increased after 4 and $10 \mathrm{~h}$ of Al exposure, respectively. In triticale, the rate of malate and citrate release was increased after 6 and $12 \mathrm{~h}$ of $\mathrm{Al}$ treatment, respectively. The lag phase between the moment of addition of $\mathrm{Al}$ and the onset of $\mathrm{OA}$ release by roots, together with the gradual increase of release with time, indicate that activation of genes related to the metabolism and membrane transport of these compounds might be required. However, to date the product generated by the activation of genes is unknown.

\section{Effect of $\mathrm{Al}$ on root exudation of other Al-complexing agents}

Organic and inorganic molecules other than OA have been identified in root exudates of plants suffering from $\mathrm{Al}$ toxicity. In a study with three maize varieties showing differential resistance to Al, Kidd et al. (2001) observed high exudation rates of the phenolics catechol, catechin, quercetin and curcumin. The amounts released correlated well with the resistance of the varieties to Al. Exudation of OA was also observed with these maize plants, but apart from being released in small amounts compared to the phenolic compounds (only $5 \%$ of the total exuded), OA release did not correlate with the general resistance shown by the three varieties to $\mathrm{Al}$. Interestingly, oxalate was the main OA detected in root exudates, with amounts up to 10 times that of citrate or aconitate, the other two acids measured. Further examples are the release of Al-binding polypeptides (Basu et al., 1994) and phosphate (Pellet et al., 1995; Pellet et al., 1996).

Lack of correlation between OA exudation and resistance to $\mathrm{Al}$ in plant species where $\mathrm{Al}$ resistance is known to exist has not been uncommon (Wenzl et al., 2001; Ma et al., 2002; Piñeros et al., 2005). While investigating the Al resistance of two varieties of rice growing in culture solution containing $\mathrm{Al}^{3+}$, Ma et al. (2002) observed a smaller relative root growth (RRG) in the indica variety Kasalath than in the japonica variety Koshihikari, together with a higher $\mathrm{Al}$ content in root tips of the former compared to the latter. Citrate dominated the OA found in the medium, but it was found at nearly equal amounts for the two rice varieties and furthermore, represented only one tenth of the citrate found in plants of rye used as control. Because rice is the grain cereal showing the highest resistance to $\mathrm{Al}$ (Ma et al., 2002), these results suggest that other mechanisms of $\mathrm{Al}$ resistance may be operating within this plant species.

Piñeros et al. (2005) made a comparative study of the physiology of $\mathrm{Al}$ resistance in maize using three Brazilian and three North American genotypes of significantly different Al resistance. They found an inverse correlation between root tip Al content and RRG. However, a lack of correlation between RRG and root citrate release was observed with the six genotypes. This was mainly due to an Al-sensitive line (Mo17) that had the greatest rate of citrate release among the maize lines. It thus led the authors to investigate other possible mechanisms for conferring resistance to $\mathrm{Al}$ such as, alkalinization of the rhizosphere, changes in internal root concentration of citrate, Al translocation to the shoot and exudation of other Al-chelating compounds. Exudation of malate and phosphate was not found to differ among genotypes. Moreover, malate and phosphate release was constitutive, that is, independent of the presence of $\mathrm{Al}$ in solution. All the other mechanisms investigated could not explain the differential resistance observed among the maize lines. The authors suggested that, besides citrate, other Alchelating compounds, including phenolics, occur in maize. They further suggested that $\mathrm{Al}$ resistance in maize is a complex trait and will need an interdisciplinary approach (genetic, molecular, and physiological) for its elucidation.

\section{Internal detoxification of $\mathrm{Al}$ by $\mathrm{OA}$}

About one hundred plant species accumulate $\mathrm{Al}$ in their above-ground parts without showing symptoms of Al intoxication (Barceló and Poschenrieder, 2002). Several mechanisms of Al tolerance have been proposed, including chelation of $\mathrm{Al}$ in the cytosol, compartmentation in the vacuole, Al-binding proteins, evolution of Al-resistant enzymes, and elevated enzyme activity (Taylor, 1991). Foy (1984) defines Al accumulator plants as those with more than $1000 \mathrm{mg} \mathrm{kg}^{-1}$ of $\mathrm{Al}$ in the leaves. These localised high concentrations of $\mathrm{Al}$ in shoots suggest that $\mathrm{Al}$ accumulator plants developed sophisticated mechanisms for the uptake and translocation of $\mathrm{Al}$ from roots to leaves. Ma and Hiradate (2000), based on their findings, proposed a conceptual model to explain the high capacity of buckwheat to absorb, transport and accumulate $\mathrm{Al}$ in the leaves. In this model, $\mathrm{Al}^{3+}$ ions cross the plasma membrane through transport proteins and, once inside the cell, are chelated by oxalate, present in the cytosol at concentrations as high as $8.8 \mathrm{mM}$ (Ma et al., 1998). Before the metal is released to the xylem vessels, ligand exchange occurs and $\mathrm{Al}$ is transported to the leaves as Al-citrate complexes. Once in the leaves, ligand exchange occurs again and $\mathrm{Al}$ is sequestered in vacuoles as 1:3 Al: oxalate complexes (Shen et al., 2002).

The organic ligand used by the plant to inactivate $\mathrm{Al}$ in the symplast varies between species. Al appears mostly complexed with catechins and OA in tea (Camellia sinensis 
L., Nagata et al., 1992), with citrate in ornamental hydrangea (Hidrangea macrophylla, Ma et al., 1997c) and with oxalate in melastoma (Melastoma malabathricum, Watanabe et al., 1998). Interestingly, part of $\mathrm{Al}$ resistance in buckwheat also correlates to Al-induced oxalate release by the roots (Zheng et al., 1998b).

\section{Altered cell OA metabolism induced by Al}

Aluminium-induced disturbances in biochemical pathways of OA metabolism as well as their relation with OA accumulation in roots have not yet been comprehensively studied, in contrast to the much better characterised process of Al-induced exudation of OA by plant roots. Cellular OA metabolism involves an array of enzymes that are interrelated and function in coordination with each other but the set of metabolic changes induced by Al that lead to altered concentrations of carboxylic acids in roots remains obscure. A diagrammatic representation of carbon (C) pathways relevant to the status of particularly malate and citrate in root cells is presented in figure 1. Since malate and citrate are both intermediate metabolites of the TCA cycle, their accumulation in root cells may result from an increase in their synthesis and/or from a reduction in their conversion into their succeeding metabolites in the TCA cycle. Therefore, any effect of $\mathrm{Al}$ on the activity of citrate synthase (CS), aconitase (Aco), and malate dehydrogenase (MDH), would interfere directly in citrate and malate metabolism. Exclusively in plant cells, malate can be alternatively converted to pyruvate by the action of malic enzyme, and thereby increase the supply of substrate for the synthesis of citrate (Taiz and Zeiger, 2002). Moreover, changes in the activity of phosphoenolpyruvate carboxylase (PEPC) could have a marked effect on cell carbon supply and thus on OA metabolism (Naik and Nicholas, 1986; Ryan et al., 2001).

Studies of the effects of $\mathrm{Al}$ on these key enzymes and on $\mathrm{OA}$ root accumulation have been undertaken with a number of economically important plant species, with results summarised in table 2. Excess Al leads to higher concentrations of $\mathrm{OA}$ in the roots, but they do not result specifically from the metabolic activity of the tissue where these changes are found. These findings raise the question of how root cells can sustain high rates of exudation, since the amounts of OA exuded represent a significant fraction of the OA content found in the exuding root tissue (table 3; Ryan et al., 1995). The activity of the tested root enzymes has, in most cases, not shown any alteration when plants were exposed to $\mathrm{Al}$ whereas changes in the concentration of $\mathrm{OA}$ in

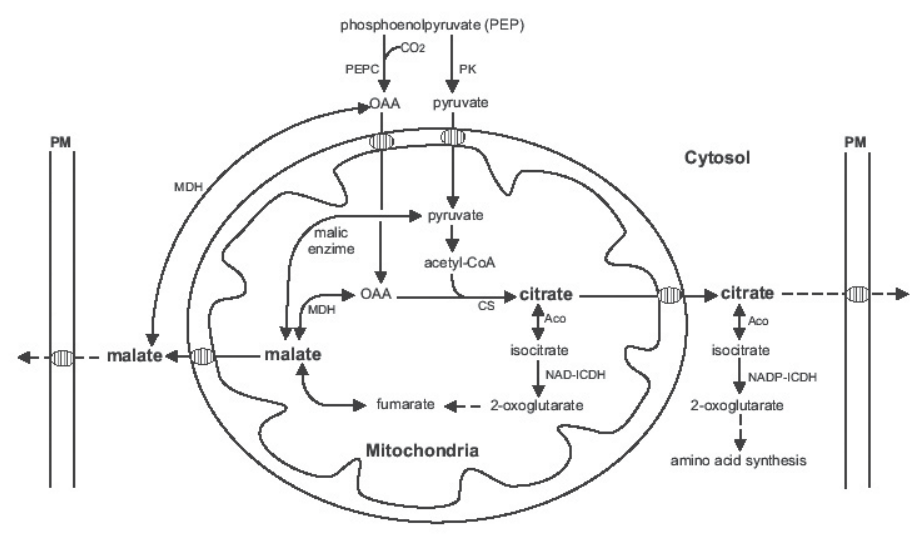

Figure 1. Diagrammatic representation of carbon pathways in plant cells related to malate and citrate metabolism. Aco, aconitase; $\mathrm{CS}$, citrate synthase; $\mathrm{MDH}$, malate dehydrogenase; NAD-ICDH, NAD specific isocitrate dehydrogenase; NADP-ICDH, NADP specific isocitrate dehydrogenase; OAA, oxaloacetate; PEPC, phosphoenolpyruvate carboxylase; PK, pyruvate kinase; PM, plasma membrane. Hatched ellipses on the plasma membrane and mitochondria denote membrane transporters.

root tissues have been found in the majority of the cases, with a notorious inter and intraspecific variation. Examination of the results of citrate and malate accumulation within each plant species suggest a positive relationship between $\mathrm{Al}$ resistance and the capacity to increase or at least to maintain the tissue concentration of citrate and malate, and this holds not only for root tips but also for the whole root. Although a similar relationship was observed previously with a group of five wheat genotypes (Foy et al., 1990), the hypothesis that increases in $\mathrm{OA}$ accumulation are associated with Al resistance needs to be further investigated, especially because internal root $\mathrm{OA}$ concentration itself cannot be used to explain Al resistance (Mariano and Keltjens, 2004). Control of internal OA concentration seems to also involve a feedback mechanism. Blockage of citrate exudation by niflumic acid, a potent anion channel inhibitor, did not result in increased internal concentration of citrate in roots of barley (Zhao et al., 2003).

On the other hand, a recent report presented circumstantial evidence in favour of a regulatory association between metabolic activity, increased production of root $\mathrm{OA}$, and even enhanced root efflux in Cassia tora (Yang et al., 2004). A time course study with seedlings of this tropical herb revealed that increases in CS activity and in citrate accumulation in root tips already occurred within the initial $3 \mathrm{~h}$ of $\mathrm{Al}$ treatment, while a substantial exudation of citrate began $6 \mathrm{~h}$ after the $\mathrm{Al}$ exposure. Concomitantly, aconitase activity in the tips of Altreated roots was always suppressed compared with controls. Temporal increases in CS and falls in aconitase activities 
Table 2. Relative activity of enzymes and organic acid anion (OA) concentration in roots of plant species where Al-induced root OA exudation is correlated with $\mathrm{Al}$ resistance. Values are expressed as no change $(=)$, enhanced activity / increased accumulation (+\%), or reduced activity / decreased accumulation $(-\%)$ relative to the respective controls without $\mathrm{Al}$. Symbols: $\mathrm{Al}$, response to $\mathrm{Al}$ where $\mathrm{R}=$ resistant and $\mathrm{S}=$ sensitive; CS, citrate synthase; Aco, aconitase; MDH, malate dehydrogenase; PEPC, phosphoenolpyruvate carboxylase; NADP-ICDH, NADP specific isocitrate dehydrogenase; Cit, citrate; Mal, malate; Oxa, oxalate; wr, whole root

\begin{tabular}{|c|c|c|c|c|c|c|c|c|c|c|c|}
\hline $\begin{array}{l}\text { Plant } \\
\text { species }\end{array}$ & Root part & $\mathrm{Al}$ & $\mathrm{CS}$ & Aco & $\mathrm{MDH}$ & PEPC & $\begin{array}{l}\text { NADP- } \\
\text { ICDH }\end{array}$ & Cit & Mal & Oxa & Ref. $^{a}$ \\
\hline & $\mathrm{mm}$ & & & & & & & & & & \\
\hline \multirow[t]{4}{*}{ Barley } & wr & $\mathrm{R}$ & & & & & & -12 & +211 & & (1) \\
\hline & & $\mathrm{S}$ & & & & & & -51 & +25 & & \\
\hline & $0-10$ & $\mathrm{R}$ & $=$ & & & & & +42 & & & (14) \\
\hline & & $\mathrm{S}$ & $=$ & & & & & -7 & & & \\
\hline S. senna & $0-5$ & $\mathrm{R}$ & +67 & -58 & $=$ & $=$ & $=$ & +96 & & & (2) \\
\hline \multirow[t]{8}{*}{ Maize } & wr & $\mathrm{R}$ & & & & & & +38 & +790 & & (3) \\
\hline & & $\mathrm{S}$ & & & & & & +65 & +620 & & \\
\hline & $0-20$ & $\mathrm{R}$ & & & & & & +260 & & & (4) \\
\hline & & $\mathrm{S}$ & & & & & & +320 & & & \\
\hline & wr & $\mathrm{R}$ & & & & & & +95 & +81 & & (5) \\
\hline & & $\mathrm{S}$ & & & & & & +165 & +9 & & \\
\hline & $0-15$ & $\mathrm{R}$ & & & & +124 & & +134 & +269 & & (15) \\
\hline & & $\mathrm{S}$ & & & & +38 & & +120 & +153 & & \\
\hline \multirow[t]{3}{*}{ Rye } & $0-10$ & $\mathrm{R}$ & +30 & & $=$ & $=$ & $=$ & & & & (6) \\
\hline & $0-5$ & $\mathrm{R}$ & +21 & & & & & & & & (7) \\
\hline & $5-20$ & $\mathrm{R}$ & $=$ & & & & & & & & \\
\hline \multirow[t]{7}{*}{ Soybean } & wr & $\mathrm{R}$ & & & & & & -12 & -84 & -28 & (8) \\
\hline & & $\mathrm{S}$ & & & & & & -37 & -86 & +67 & \\
\hline & $0-10$ & $\mathrm{R}$ & +15 & & & $=$ & $=$ & $=$ & $=$ & & (9) \\
\hline & $0-5$ & $\mathrm{R}$ & & & & & & +118 & +13 & & (10) \\
\hline & & $\mathrm{S}$ & & & & & & -39 & +28 & & \\
\hline & 5-base & $\mathrm{R}$ & & & & & & -6 & +175 & & \\
\hline & & $\mathrm{S}$ & & & & & & -24 & +90 & & \\
\hline \multirow[t]{4}{*}{ Triticale } & $0-5$ & $\mathrm{R}$ & $=$ & & $=$ & $=$ & +30 & +100 & $=$ & & (11) \\
\hline & & $\mathrm{S}$ & $=$ & & $=$ & $=$ & +40 & +100 & $=$ & & \\
\hline & $10-20$ & $\mathrm{R}$ & $=$ & & $=$ & $=$ & $=$ & +200 & +100 & & \\
\hline & & $\mathrm{S}$ & & & & & & +100 & +100 & & \\
\hline \multirow[t]{5}{*}{ Wheat } & $0-4$ & $\mathrm{R}$ & & & & & & & +6 & & (12) \\
\hline & & $\mathrm{S}$ & & & & & & & -21 & & \\
\hline & $0-3$ & $\mathrm{R}$ & & & $=$ & $=$ & & & & & (13) \\
\hline & & $\mathrm{S}$ & & & +24 & +51 & & & & & \\
\hline & $0-10$ & $\mathrm{R}$ & $=$ & & $=$ & $=$ & $=$ & & & & (6) \\
\hline
\end{tabular}

${ }^{a}$ 1. Foy et al. (1987); 2. Yang et al. (2004); 3. Pellet et al. (1995); 4. Piñeros et al. (2005); 5. Mariano and Keltjens (2004); 6. Li et al. (2000); 7. Li et al. (2002); 8. Menosso et al. (2001); 9. Yang et al. (2001); 10. Silva et al. (2001); 11. Hayes and Ma (2003); 12. Delhaize et al. (1993); 13. Ryan et al. (1995); 14. Zhao et al. (2003); 15. Gaume et al. (2001) 
Table 3. Root citrate content and exudation of roots of an Al-resistant maize genotype (CMS36) grown at two concentrations of Al (0 or 40 $\mu \mathrm{M})$ for $28 \mathrm{~h}$. Tissue content was determined at the end of the exudation period (last $4 \mathrm{~h}$ of the $28-\mathrm{h} \mathrm{Al}$ treatment period).

\begin{tabular}{|c|c|c|c|c|}
\hline \multirow{2}{*}{ Root zone } & \multicolumn{2}{|c|}{ Citrate content (nmol) } & \multicolumn{2}{|c|}{ Citrate exudation $\left(\mathrm{nmol} 4 \mathrm{~h}^{-1}\right)$} \\
\hline & Al 0 & $\mathrm{Al} 40$ & $\mathrm{Al} 0$ & $\mathrm{Al} 40$ \\
\hline Whole root & 21.2 & 31.9 & 0.27 & 1.96 \\
\hline $\begin{array}{l}\text { Apical } 10 \mathrm{~mm} \text { segment: } \\
\text { absolute } \\
\text { relative ( } \% \text { of whole root) }\end{array}$ & $\begin{array}{c}4.04 \\
19\end{array}$ & $\begin{array}{c}5.16 \\
16\end{array}$ & $\begin{array}{c}0.12 \\
44\end{array}$ & $\begin{array}{c}1.21 \\
62\end{array}$ \\
\hline
\end{tabular}

with Al treatments were associated with a gradual increase in root accumulation and exudation of citrate, which clearly characterised and confirmed the pattern II type of exudation in this species (Ma et al., 1997b).

The lack of alteration in the activity of PEPC after Al treatment shown by these studies is particularly interesting, since reactions where phosphoenolpyruvate (PEP) is carboxylated by PEPC to produce oxaloacetate (OAA) are known to function as a source of $\mathrm{C}$ for the anaplerotic operation of the TCA cycle (Naik and Nicholas, 1986; Taiz and Zeiger, 2002). Conditions in which OA are being released from roots (e.g. OA exudation by Al-stressed plants) require that $\mathrm{C}$ be replaced either by photosynthesis or nonphotosynthetic $\mathrm{CO}_{2}$ fixation via PEPC (Johnson et al., 1994). Al-induced disturbance of NADP-ICDH function could also affect citrate accumulation in the cell, since cytosolic NADP-ICDH is probably the major pathway for the catabolism of citrate after its transport out of mitochondria and conversion to isocitrate by cytosolic Aco (Delhaize et al., 2003).

Comparatively, studies on OA metabolism and C partitioning within $\mathrm{P}$-starved plants have revealed a multitude of metabolic changes induced by $\mathrm{P}$ deficiency that ultimately resulted in accumulation of $\mathrm{OA}$ in the root, and eventually in their exudation to the external medium. For instance, $\mathrm{OA}$ accumulation in roots and shoots of P-deficient oilseed rape plants coincided with enhanced activities of PEPC in the shoot and in the root tip (Hoffland et al., 1992). With white lupin (Lupinus albus L.), a species well-known for its excellent ability to solubilise and absorb P from rock phosphate, Johnson et al. (1994, 1996) observed that under $\mathrm{P}$-stress conditions, $\mathrm{C}$ fixation in roots (nonphotosynthetic C fixation) plays an important role in $\mathrm{C}$ exudation. Carbon fixed in roots of P-starved plants, via an enhanced activity of PEPC and accompanied by higher MDH and CS activities, contributed about 25 and $35 \%$ of the $\mathrm{C}$ exuded as citrate and malate respectively.

Aluminium can also have a significant, yet indirect, effect on cell OA metabolism by disturbing the pattern of mineral nutrient uptake and hence altering the cationanion uptake balance of the cell. The maintenance of electroneutrality within plant cells and organelles is achieved by $\mathrm{pH}$-dependent changes in the size of the OA pool through carboxylation and decarboxylation reactions, often referred to as the biochemical pH-stat (Haynes, 1990). The adverse effects of $\mathrm{Al}$ on mineral nutrient uptake are well documented (Foy, 1984), and among its negative effects on absorption of macronutrients, $\mathrm{Al}$ has been shown to interfere strongly with the nitrogen nutrition of plants. With maize, Al drastically inhibited the absorption of nitrate $\left(\mathrm{NO}_{3}{ }^{-1}\right)$, but not that of ammonium $\left(\mathrm{NH}_{4}^{+}\right)$, which was actually slightly stimulated under Al stress (Keltjens and van Ulden, 1987; Mariano and Keltjens, unpublished data). The resulting alkaline nutrient uptake pattern would result mainly in decarboxylation of malate, but also in $\mathrm{H}^{+}$extrusion from roots to compensate for the excess of positive charges, resulting from $\mathrm{NH}_{4}{ }^{+}$uptake and assimilation, over negative ones. In addition, an inherent complicating fact is that the inhibitory effect of $\mathrm{Al}$ on the uptake of $\mathrm{NO}_{3}{ }^{-}$is stronger in Al-sensitive genotypes than in Al-resistant ones (Keltjens, 1987; Keltjens and van Ulden, 1987). With genotypes showing differential resistance to $\mathrm{Al}$, this toxic metal would almost certainly lead to differences in OA concentration in roots that might be unrelated to its specific action on OA metabolism and/or to the capacity of the genotypes to release these $\mathrm{C}$ compounds as a protective mechanism against $\mathrm{Al}$.

We will certainly need a holistic approach that considers enzymes and metabolites both upstream and downstream of citrate and malate as well as their subcellular pools in order to obtain some insight into their dynamics within and transport out of the cell.

\section{Linking internal OA concentration with OA exudation}

Attempts to link internal root concentration and root exudation of OA have been made with Al-stressed plants, with an implicit assumption that higher internal concentrations 
would lead to higher root exudation rates. However, no correlation is apparent between internal concentration and rate of exudation in plant species where root OA release is stimulated by Al (Delhaize et al., 1993; Pellet et al., 1995; Silva et al., 2001). Aluminium activates a five to tenfold increase in malate exudation in wheat roots (Delhaize et al., 1993; Ryan et al., 1995). Al-stimulated efflux of malate from the terminal 3-mm root segment was tenfold greater than either of the next two 3-mm segments. This pattern was not correlated with the internal distribution of malate, which was actually lower in the apical segment. The high rate of efflux was maintained for several hours and the cumulative release in $4 \mathrm{~h}$ represented more than three times the malate present in the tissue before addition of $\mathrm{Al}$, demonstrating that malate synthesis occurred in the excised tissue during the period of efflux. Furthermore, the much greater stimulation of malate efflux from root apices of the Al-resistant compared to those of the Al-sensitive genotype could not be explained by differences in the activities of PEPC or MDH (Ryan et al., 1995).

Given the uneven distribution of organic solutes, including $\mathrm{OA}$, and of $\mathrm{OA}$ exudation within a single plant root (Marschner, 1995; Pellet et al., 1995; Jones, 1998; Mariano and Keltjens, 2003), much caution is needed when studying their interrelation in the root system. A remarkable accumulation of the tricarboxylic acid citrate was observed in the apical region $(0-10 \mathrm{~mm})$ of maize roots growing under optimal conditions, contrasting with much lower concentrations in the more mature zones, especially in that between the root tip and the basal region with lateral roots (figure 2) (Mariano 2003; Mariano and Keltjens, unpublished data). This great localised concentration reflects the high demand of photosynthates in the growing parts of the root for the formation of new root biomass, followed by high rates of metabolic activity and a concomitant consumption of $\mathrm{O}_{2}$ in these apical regions (Jones and Darrah, 1996; Li et al., 2002). Conversely, maize roots exposed to $\mathrm{Al}$ showed a rather homogeneous spatial internal distribution of citrate along the longitudinal axis (figure 2).

A constitutive basal release of OA into the soil is observed in the apical parts of roots growing without any external stimuli (Jones, 1998, Ryan et al., 2001). This constant and low release is independent of the internal pool of citrate found in this part of the root. Moreover, high concentrations of citrate in spatially-isolated segments of intact maize roots did not confer high rates of exudation, as shown by the lack of correlation between internal concentration and exudation observed with and without Al (figure 3). It indicates that the internal concentration of citrate itself is not the driving force of citrate exudation from roots, but $\mathrm{Al}$ can induce a high permeability to citrate in root cells. Furthermore, contrary to the distribution of the internal citrate content of the root, where the apical $10 \mathrm{~mm}$ accounted for $15-20 \%$ of the total root citrate, this apical part accounted for as much as 44 and $62 \%$ of the total citrate exuded by the entire root in $4 \mathrm{~h}$ (table 3). Location of sites of high OA release in apices not only coincides with this segment being the most Al-sensitive region of the root but also shows that only cells at a certain stage of development are able to release OA in response to toxic $\mathrm{Al}$ ions.

Besides showing an altered distribution of internal root citrate, Al-treated roots contained 50\% more citrate than roots not treated with $\mathrm{Al}$ (table 3 ). The cortical as well as the stellar tissue of maize roots show a capacity to increase their citrate concentrations after root exposure to $\mathrm{Al}$ (Piñeros et al., 2002). Because citrate and malate are simple intermediate metabolites in the TCA cycle and the enzymatic machinery for their production is already present in the cell, it would appear, in principle, that cells along the whole root can respond to $\mathrm{Al}$ through an altered production and storage of these two OA.

The stimulated release of citrate verified with maize roots treated with $40 \mu \mathrm{M}$ Al resulted in a partial loss of root citrate to the outer medium. This loss represented about 5\% of the total citrate content of the root but could represent much more (about 25\%) if only the apical root segment were considered (table 3 ). These data reinforce the hypothesis that a continual synthesis of citrate is required to sustain such a high rate of citrate exudation, which would otherwise completely deplete the citrate reserve of that root segment within a

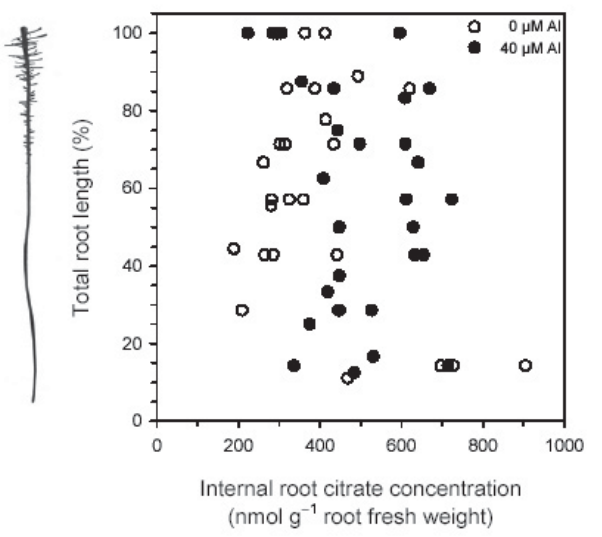

Figure 2. Distribution of internal citrate concentration along the main root axis of an Al-resistant maize genotype (CMS36) exposed to 0 or $40 \mu \mathrm{MAl}$ for $28 \mathrm{~h}$. A root axis as used in the experiments is schematised on the left-hand side for reference. 
few hours. It becomes very likely therefore that apart from the synthesised OA, that transported from other parts of the root system or the plant should also be contributing to the continual release of OA by root apices. Equally possible is the basipetal transport of photosynthetically fixed $\mathrm{C}$ compounds, including sugars, that can be locally converted into OA before release to the external medium. Transport of sugars might constitute an important source of energy as well as $\mathrm{C}$ itself to the $\mathrm{C}$ drain that exudation may represent (up to $25 \%$ of the photosynthetically fixed C, Johnson et al., 1996; Jones, 1998). With plants of oilseed rape suffering from $P$ deficiency, Hoffland et al. (1992) demonstrated that part of the citrate accumulated in the roots had its origin in the shoots. Citrate produced from photosynthetically fixed $\mathrm{C}$ was transported via the phloem towards the root where it was stored in the exudation region. Deficiency of $\mathrm{P}$ also led to an increase in the transport of sugars from shoots to roots. Because no increase in the concentration of malate was observed in the phloem sap, these authors suggested that malate was probably newly synthesised in the cells of the accumulating root segment from sugars imported from the shoots. The pattern of citrate concentration shown by maize roots after $28 \mathrm{~h}$ of $\mathrm{Al}$ treatment (figure 2) should reflect the net result of a combination of the different processes described, i.e. cell OA metabolism of roots and shoots (biosynthesis and decomposition), reallocation and storage, and root exudation. For such a process, a regulation mechanism operating at whole plant level might be expected.

Assuming that the aerial parts of the plant would also contribute to root exudation (Yang et al., 2001), the role of signal molecules in altering the OA metabolism in the shoot soon after Al exposure would be of primary importance. Due to the high binding affinity of Al for cellular components of the roots, $\mathrm{Al}$ is not usually translocated to the upper parts of plants, even when root growth is severely inhibited (Marschner, 1995). Therefore, it is most unlikely that Al itself can trigger increases in OA biosynthesis in the shoots soon after $\mathrm{Al}$ exposure, especially with those plant species that show a minimal transport of $\mathrm{Al}$ to leaves.

It is noteworthy that current studies with OA metabolism, transport and exudation in response to $\mathrm{Al}$ stress have either focused on the whole root system or on the first few millimetres of the root tip, which does not allow the assessment of $\mathrm{C}$ partitioning in Al-stressed plants. In future studies we will need a more integrative model to understand the changes in OA metabolism induced by Al that lead to an altered accumulation of OA in shoots and roots and eventually to an enhanced release by roots and resistance to $\mathrm{Al}$.

\section{Al-activated transport of $\mathrm{OA}$ across the cell membrane}

Monomeric Al ions induce a high permeability to $\mathrm{AO}$ in root cell membranes. This induction is highly specific to Al since other di and trivalent metals like lead $\left(\mathrm{Pb}^{2+}\right)$, cadmium $\left(\mathrm{Cd}^{2+}\right)$, manganese $\left(\mathrm{Mn}^{2+}\right)$, lanthanum $\left(\mathrm{La}^{3+}\right)$, gallium $\left(\mathrm{Ga}^{3+}\right)$, indium $\left(\mathrm{In}^{3+}\right)$, and ytterbium $\left(\mathrm{Yb}^{3+}\right)$ were unable to induce exudation of OA from roots of several plant species (Ryan et al., 1995; Ma et al., 1997b; Li et al., 2000, 2002).
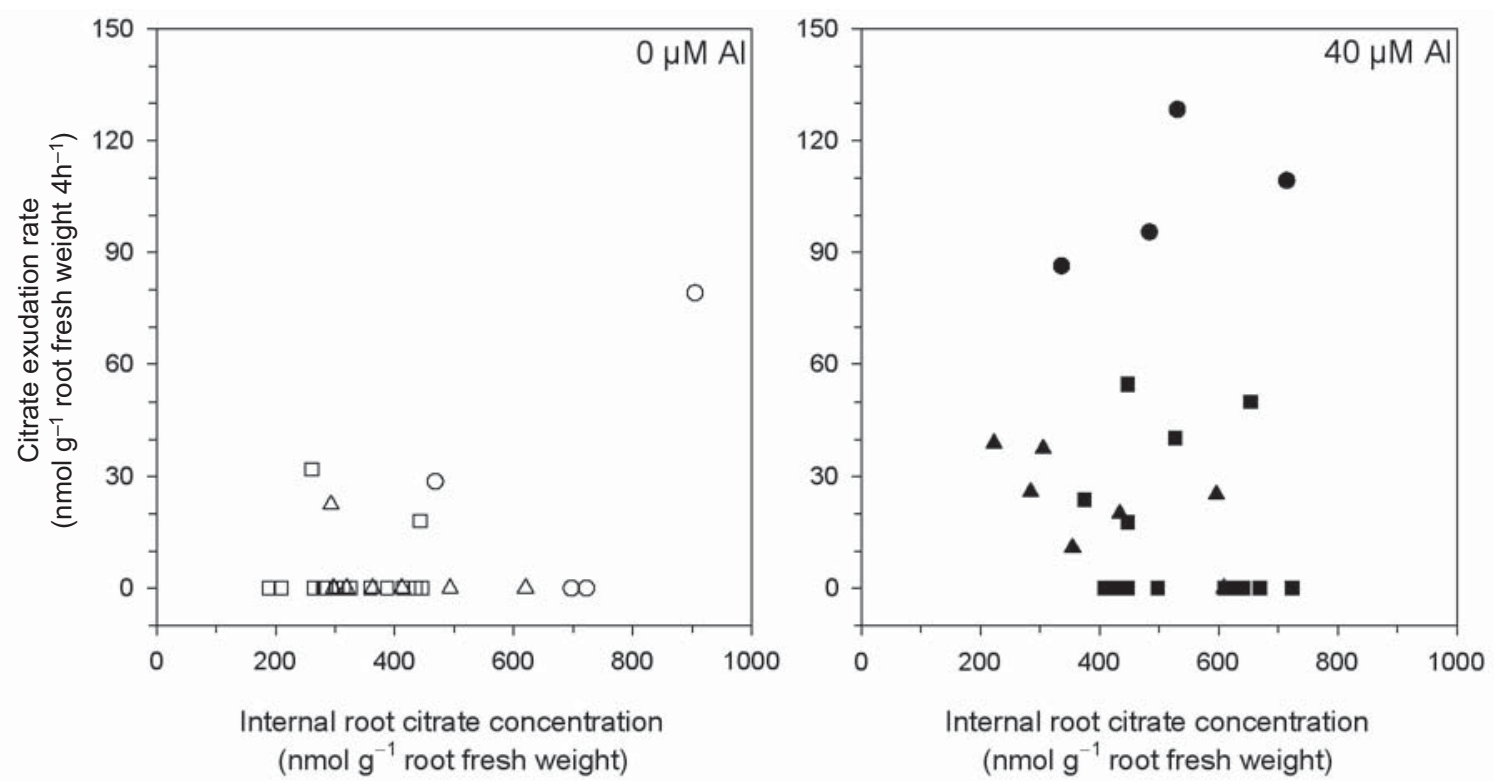

Figure 3. Internal root citrate concentration and root citrate exudation of root segments of the intact main root of an Al-resistant maize genotype (CMS36) exposed to 0 or $40 \mu \mathrm{M} \mathrm{Al}$ for $28 \mathrm{~h}$.,$\bigcirc \bullet$, root tip; $\square \mathbf{\square}$, mature zone without lateral roots; $\triangle \boldsymbol{\Delta}$, mature zone with lateral roots. 
This Al-specific induction is confined to the regions of root meristems (Pellet et al., 1995; Kollmeier et al., 2001; Mariano and Keltjens, 2003) and Al must be in direct and continuous contact with the root before activated exudation is observed. Soybean plants whose root system was spatially divided and partially treated with $\mathrm{Al}$ showed exudation of citrate only from (tips of) roots exposed to the toxic metal (Yang et al., 2001). The specificity of the mechanism controlling exudation under $\mathrm{Al}$ stress can be further appreciated by comparing it to the mechanism controlling root exudation induced by $\mathrm{P}$ deficiency, where the site of exudation occurs along the root axis as far back from the tip as where the root has contact with the rock phosphate (Hoffland et al., 1992).

Anion channels are found in plants cells and play an important role in cell signal transduction, osmoregulation, nutrition and metabolism (Barbier-Brygoo et al., 2000; Ma et al., 2001; Ryan et al., 2001). Protons $\left(\mathrm{H}^{+}\right)$are continuously pumped from the cytoplasm to the apoplast by $\mathrm{H}^{+}$-ATPases, thus generating a negative potential $(-100$ to $-200 \mathrm{mV})$ across the plasma membrane (negative inside). This negative potential and the gradient of concentration between cytoplasm and apoplast allow the passive efflux of anions to the apoplast via anion channels (Barbier-Brygoo et al., 2000).

Anion channels that are specifically activated by extracellular $\mathrm{Al}^{3+}$ have been reported in protoplasts isolated from root apices of Al-resistant wheat (Ryan et al., 1997; Zhang et al., 2001) and maize (Kollmeier et al., 2001; Piñeros and Kochian, 2001; Piñeros et al., 2002), and have been proposed as the mediators of OA transport across the cell membrane. Indeed, the species-specific pattern of OA release (Table 1), together with the observation that root segments containing $\mathrm{OA}$ in the highest concentration are not the ones showing the highest rates of release (i.e. the gradient of concentration itself does not determine efflux rate), suggest that specific membrane transporters that can be activated by Al might well be involved. Further evidences that support this hypothesis are: 1) these anion channels are activated specifically by $\mathrm{Al}^{3+}$, while $\mathrm{La}^{3+}$ is not able to replace it; 2) apart from the anion $\mathrm{Cl}^{-}$that is mostly used in electrophysiological studies, Al-activated anion channels have shown permeability to the most important OA involved in the $\mathrm{Al}$ resistance mechanism (i.e. malate ${ }^{2-}$ and citrate $^{3-}$ ); 3) in the presence of anion channel blockers, anion currents as well as exudation rates are strongly inhibited; 4) Al-activated anion channels have been observed in the apical region of roots, more specifically in the distal transition zone (DTZ, 1-2 mm from the tip), which coincides with this region being the most sensitive to $\mathrm{Al} ; 5)$ trivalent $\mathrm{Al}$ ions activate anion channels more often in cells from Al-resistant than from Al-sensitive lines, which correlates with higher rates of OA release observed in roots of the former.

The mechanism by which $\mathrm{Al}$ activates these channels is not known precisely. A model proposed in details by Ma et al. (2001) and Ryan et al. (2001), suggests that the Al activation of these anion channels could occur through the following possibilities: exudation pattern $\mathrm{I}-\mathrm{a}$ ) direct interaction between $\mathrm{Al}^{3+}$ and the channel in the cellular membrane; b) indirect interaction between $\mathrm{Al}^{3+}$ and the channel, via a specific receptor in the cellular membrane and close to the channel; c) $\mathrm{Al}^{3+}$ enters the symplast to activate the anion channels; exudation pattern $\mathrm{II}-\mathrm{Al}^{3+}$ interacts with a receptor in the cellular membrane that in turn is able to activate the channel through a signal cascade that can involve gene activation, protein synthesis, OA metabolism and transport. For example, Piñeros and Kochian (2001) observed that the anion current is activated by $\mathrm{Al}^{3+}$ in outside-out patches of Al-resistant maize, suggesting that $\mathrm{Al}$ does not need to enter the symplast to activate the anion channels.

Recently, an Al-activated membrane protein that mediates the transport of malate out of the cell was reported by Sasaki et al. (2004). This protein is encoded by a wheat gene named ALMT1 (aluminum-activated malate transporter), and is constitutively expressed in the root apices, with higher expression in the Al-resistant lines than in the near-isogenic but Al-sensitive ones. Further studies on the factors controlling the permeability of this protein to malate will certainly produce interesting insights into $\mathrm{Al}$ resistance.

\section{Genetic manipulation of OA metabolism and exudation in plants}

Plant breeders can take advantage of genetic engineering by which useful genes are made available from virtually any species and this can speed up the introgression of new desirable traits in crop species. Researchers have manipulated the biosynthetic capacity of cells with a view to produce and accumulate higher amounts of OA, in the hope that this will ultimately result in an altered root exudation profile and $\mathrm{Al}$ resistance of a given plant genotype.

As pointed out by Rengel (2002), increase of synthesis and, eventually, accumulation of OA in root cells are not a guarantee of high rates of root exudation. Rather, effective exudation of OA into the rhizosphere relies on at least three processes: a signalling sequence, effective biosynthetic machinery producing relatively large amounts of $\mathrm{OA}$, and a 
membrane transporter that allows transfer of OA out into the root apoplast and rhizosphere.

Table 4 summarises the attempts to obtain transgenic plants with higher $\mathrm{Al}$ resistance by enhancing OA exudation. The most well-known example of a successful achievement in this direction is the work of de la Fuente et al. (1997). These authors transferred a citrate synthase gene from the bacterium Pseudomonas aeruginosa into tobacco and papaya (Carica papaya L.) and recorded increases of 2- to 3-fold in CS activity, up to 10-fold in internal citrate concentration and up to 4-fold in root citrate efflux with plants of both species grown in Al-containing nutrient solution. The transgenic tobacco plants also had lower root growth inhibition and lower hematoxylin staining of the root apex than tobacco plants containing an empty vector, when growing under $\mathrm{Al}$ stress. The strategy of overexpressing enzymes involved in OA metabolism has proven to be effective to enhance $\mathrm{OA}$ exudation and to increase $\mathrm{Al}$ resistance with other transgenic plants. Arabidopsis thaliana expressing a CS from carrot (Dancus carota L.) (Koyama et al., 2000), alfalfa overexpressing an alfalfa (Medicago sativa L.) $\mathrm{MDH}$ (Tesfaye et al., 2001), and oilseed rape transformed with a CS from A. thaliana (Anoop et al., 2003) all had increased concentrations and/or activity of $\mathrm{CS}$ or $\mathrm{MDH}$, that were correlated with higher release of OA by roots.

Nevertheless, the strategy has also failed in some cases. Delhaize et al. (2001) argued that expression of the $P$. aeruginosa citrate synthase gene in plants is unlikely to be a robust strategy for enhancing the Al resistance of plants. Delhaize and co-workers used the same lines from de la Fuente et al. (1997) and generated novel tobacco lines expressing the same $P$. aeruginosa gene. The CS activity in the novel lines was up to 100 -fold greater than in the non-transformed plants but no increase in root citrate accumulation, citrate root efflux or Al resistance was observed. Moreover, Delhaize et al. (2001) could not repeat the findings of de la Fuente et al. (1997) using the same tobacco lines. Transference of the same construct to alfalfa resulted in high values of CS expression, but again it did not confer higher resistance to Al compared to non-transformed plants. Delhaize et al. (2001) then suggested that either the $P$. aeruginosa CS gene could be sensitive to the different environmental conditions used by the two research groups or the previous results on Al resistance (de la Fuente et al., 1997) and enhanced P acquisition (López-Bucio et al., 2000) could be due to other variables.

In another study, Delhaize et al. (2003) produced transgenic plants of tobacco that had marked increases in mitochondrial CS activity and large reductions in cytosolic NADP-ICDH, two enzymes with a key role in controlling cell citrate concentration, but with no differential internal citrate concentration or citrate efflux. An increased turnover of citrate where increased biosynthesis was matched by increased degradation was considered as a possible explanation but the authors also argued that the limiting step may not be the production, but rather the transport of citrate across the plasma membrane.

An important step in the use of membrane transporters of OA with an aim to improve $\mathrm{Al}$ resistance was recently taken by Delhaize et al. (2004) using the ALMT1 gene encoding a membrane malate transporter. Sasaki et al. (2004) observed that transgenic rice plants overexpressing the ALMT1 gene did not show increases in Al resistance and concluded that this was because of the natural high Al resistance observed in rice plants. Based on these findings Delhaize et al. (2004) used barley, a highly Al-sensitive species, and found that

Table 4. Transgenic plants overexpressing genes involved in OA synthesis and release.

\begin{tabular}{lcccc}
\hline Gene & $\begin{array}{c}\text { Organism } \\
\text { of origin }\end{array}$ & $\begin{array}{c}\text { Transformed } \\
\text { species }\end{array}$ & Al resistance $^{\text {Ref. }}$ \\
\hline CSb (citrate synthase) & P. aeruginosa & Tobacco, papaya & Increased \\
DcCS (citrate synthase) & Carrot & Arabidopsis & Increased & $(1)$ \\
$C S b$ (citrate synthase) & P. aeruginosa & Tobacco, alfalfa & Not changed & $(2)$ \\
$n e M D H$ (malate dehydrogenase) & Alfalfa & Alfalfa & Increased & $(3)$ \\
$P E P C$ (phosphoenolpyruvate carboxylase) & Alfalfa & Alfalfa & Not changed & $(4)$ \\
cit1 (citrate synthase) & Tobacco & Tobacco & Not changed & $(4)$ \\
$A t-m t C S$ (citrate synthase) & Arabidopsis & Oilseed rape & Increased & $(5)$ \\
$A L M T 1$ (malate channel) & Wheat & Rice & Not changed & $(7)$ \\
$A L M T 1$ (malate channel) & Wheat & Barley & Increased & $(8)$ \\
\hline
\end{tabular}

a 1. de la Fuente et al. (1997); 2. Koyama et al. (2000); 3. Delhaize et al. (2001); 4. Tesfaye et al. (2001); 5. Delhaize et al. (2003); 6. Anoop et al. (2003); 7. Sasaki et al. (2004); 8. Delhaize et al. (2004) 
Al triggered a perceptible exudation of malate from roots. The rate of malate release accompanied $\mathrm{Al}$ concentrations in solution in a dose-dependent manner, confirming the previous findings that the ALMT1 protein is an Al-gated anion channel (Sasaki et al., 2004). Moreover, the fact that malate release can be increased by the expression of an anion channel protein indicates that this mechanism of transport can be easily modulated by root apex cells and is not ratelimiting within the $\mathrm{Al}$ concentrations normally used in $\mathrm{Al}$ toxicity/resistance studies. Unfortunately, no information was made available on the internal malate concentration with the transformed plants.

Root release of OA can increase soil-P mobilisation and availability to plants (Kochian et al., 2004), and the performance of transgenic plants with higher efflux of OA has also been evaluated in P-limiting conditions. Growing in soils with low available $\mathrm{P}$, transgenic tobacco plants produced more biomass and had higher concentrations of $\mathrm{P}$ in their leaves than the control plants (López-Bucio et al., 2000). Overexpression of CS in A. thaliana (Koyama et al., 2000) and of MDH in alfalfa (Tesfaye et al., 2001) conferred higher exudation of citrate in the former and of several OA in the latter, which in both cases resulted in increased P uptake from acidic low-P soils.

It is worth noting that performance of a transgenic plant compared to non-transformed plants cannot be taken as the unique variable to assess $\mathrm{Al}$ resistance and/or P efficiency. The use of Al resistant/P efficient germplasm and (field) assays using acid soils is highly desirable to get stronger evidence on their potential use in agricultural systems. From all the studies presented in table 4, only the overexpression of the neMDH gene in alfalfa (Tesfaye et al., 2001) and the ALTM1 gene in barley (Delhaize et al., 2004) produced transgenic plants with growth comparable to an Al-resistant standard.

Knowledge of the genetic basis of OA release by roots brings, therefore, new perspectives on the use of genetically modified organisms to cultivate soils often considered Al-toxic/P-deficient problem soils. Plants with superior resistance to $\mathrm{Al}$ and higher capacity to acquire $\mathrm{P}$ conferred by exudation of high amounts of OA may help to reduce the use of soil amendments (e.g. lime) and P fertilisers, hence reducing financial and environmental costs.

\section{Transgenic plants overexpressing Al-induced genes}

There are several genes that have been found to be induced by Al stress and the effect of their overexpression in transgenic plants evaluated (Table 5). Ezaki et al. (2000) found that transgenic $A$. thaliana plants expressing a bluecopper-binding protein, a guanosine 5' diphosphate (GDP) dissociation inhibitor, a peroxidase and a glutathione S-transferase had up to 1.5 -fold higher root growth at $100 \mu \mathrm{M} \mathrm{Al}$ compared to wild-type plants. Although modest, the increase in $\mathrm{Al}$ resistance did help to better understand the mechanisms of Al toxicity, reinforcing the former view that Al causes oxidative stress, since both peroxidase and glutathione S-transferase are well-known enzymes involved in the detoxification of reactive oxygen species. In another study, the survival of $A$. thaliana seedlings in $200 \mu \mathrm{M} \mathrm{Al}$ solution was strongly enhanced by the overexpression of the soybean Alinduced IMPDH gene, which encodes a protein homologous

Table 5. Transgenic plants overexpressing genes induced by Al stress.

\begin{tabular}{|c|c|c|c|c|}
\hline Gene & $\begin{array}{c}\text { Organism of } \\
\text { origin }\end{array}$ & $\begin{array}{l}\text { Transformed } \\
\text { species }\end{array}$ & Al resistance & Ref. $^{\mathrm{a}}$ \\
\hline$A t B C P$ (Blue copper binding protein) & Arabidopsis & Arabidopsis & Increased & (1) \\
\hline AtBPI (protease inhibitor) & Arabidopsis & Arabidopsis & Not changed & (1) \\
\hline AtPOX (peroxidase) & Arabidopsis & Arabidopsis & Not changed & (1) \\
\hline HSP150 (heat shock protein) & S. cerevisiae & Arabidopsis & Not changed & (1) \\
\hline$N t G D I$ (GDP dissociation inhibitor) & Tobacco & Arabidopsis & Increased & (1) \\
\hline$N t P O X$ (peroxidase) & Tobacco & Arabidopsis & Increased & (1) \\
\hline parA (unknown function) & Tobacco & Arabidopsis & Not changed & (1) \\
\hline $\operatorname{parB}$ (glutathione S-transferase) & Tobacco & Arabidopsis & Increased & (1) \\
\hline Wali5 (Bowman-Birk protease inhibitor) & Wheat & Arabidopsis & Not changed & (1) \\
\hline WMnSOD (mitochondrial manganese superoxide dismutase) & Wheat & Oilseed rape & Increased & (2) \\
\hline Wakl (cell wall-associated receptor kinase 1) & Arabidopsis & Arabidopsis & Increased & (3) \\
\hline$I M P D H$ (inosine-5'-monophosphate dehydrogenase) & Soybean & Arabidopsis & Increased & (4) \\
\hline
\end{tabular}

a 1. Ezaki et al. (2000); 2. Basu et al. (2001); 3. Sivaguru et al. (2003); 4. Ermolayev et al. (2003) 
to inosine-5' -monophosphate dehydrogenase (Ermolayev et al., 2003). This protein is involved in the synthesis of guanine nucleotides (RNA and DNA precursors) and in cell differentiation (Ermolayev et al., 2003 and references therein).

Sivaguru et al. (2003) superexpressed the WAK1 (cell wall-associated receptor kinase 1) in A. thaliana and found that the growth of transgenic plants at $100 \mu \mathrm{M}$ Al was 3-fold higher than that of wild-type plants. The gene $W M n-S O D$ is induced by $\mathrm{Al}$ and encodes a manganese superoxide dismutase (SOD) that co-segregated with Al resistance in a wheat population (Basu et al., 1999, 2001). Transgenic oilseed rape plants overexpressing this gene had 1.5- to 2.5fold higher SOD activity, which was associated with a lower content of malondialdehyde, a marker of lipid peroxidation (Basu et al., 2001). The root growth of the genetically modified plants exposed to Al was 1.5- to 2.3-fold higher than the root growth of wild-type plants.

The findings with transgenic plants along with the wide array of function of Al-induced genes and Al toxicity symptoms indicate that the plant defences against this metal are controlled by multiple genes. This makes it quite difficult to produce Al-resistant transgenic plants using only one of these genes. A good alternative would be to use gene pyramidization, with the expression of several genes simultaneously. In fact, Ezaki et al. (2001) produced hybrids from their previous work with transgenic $A$. thaliana overexpressing the AtBCB, parB, NtPox, and NtGDI1 genes (see table 4 and Ezaki et al., 2000). While the lines containing only one transgene showed around $40 \%$ of root growth reduction, any transgenic hybrid containing two of these genes had only $20 \%$ of root growth reduction at $200 \mu \mathrm{M}$ Al solution (Ezaki et al., 2001). The combination of genes involved in both $\mathrm{Al}$ exclusion and $\mathrm{Al}$ tolerance will certainly produce transgenic plants with higher total Al resistance.

Another alternative is the identification of transcriptional factors that are at the top of the cascade that triggers the expression of several genes involved in plant defences against Al toxicity. There are several examples of the expression of a single transcriptional factor that triggers plant defences, as the case of the $A$. thaliana $C B F 1$ and $C B F 4$ genes which activate several genes, increasing tolerance to abiotic stress such as low temperature and water deficit (Haake et al., 2002; Lee et al., 2003). To this end it is expected that experiments with DNA microarrays, which allow high throughput gene expression profiling, will have a huge impact on the discovery of new Al-induced genes. It is surprising that so far only one preliminary experiment on Al resistance has been evaluated using this technology (Hoekenga et al., 2003).

\section{Promoters used to overexpress transgenes}

The strong $35 \mathrm{~S}$ promoter has been widely used to direct the expression of the transgenes shown in table 4 . The only exception is the work of Delhaize et al. (2004), where the maize Ubil promoter from an ubiquitin gene was used. It is well known that the $35 \mathrm{~S}$ promoter is strongly expressed in most plant tissues. Since the site of Al toxicity is the root apex, promoters that express transgenes only in this region would avoid the waste of metabolic energy and undesirable phenotypes due to ectopic expression. For instance, the low biomass production of transgenic plants grown in soil with neutral $\mathrm{pH}$, where the OA release mechanism was not expected to be activated, might be associated with the use of the $35 \mathrm{~S}$ promoter to express the neMDH gene, as pointed out by Tesfaye et al. (2001). Interestingly, no differences were observed in root growth between wild-type and transgenic barley plants expressing the ALMT1 gene under the control of the constitutive Ubil promoter (Delhaize et al., 2004). Unfortunately, these authors did not present data on the total plant biomass that would permit a comparison with data of Tesfaye et al. (2001).

It is worth mentioning that public concerns towards genetically modified crops must also be taken into account when planning the production of transgenic plants (Doering, 2004). In this sense, the expression of transgenes in plant parts that will be used for human and animal nutrition is not desirable, reinforcing the need of specific promoters. In any case, a desirable promoter for engineering Al resistance would be highly expressed in the root apex and only in the presence of Al. Recently Ezaki et al. (2004) evaluated the expression pattern of two Al-induced genes encoding GST proteins from Arabidopsis. Although both AtGST1 and AtGST11 promoters are induced by $\mathrm{Al}$, they were mainly active in the leaves and showed very low activity in roots, making them unsuitable candidates to direct the expression of genes aimed at $\mathrm{Al}$ resistance. We have isolated a promoter from a maize gene that is expressed only in epidermis of the root tip (Maron et al., unpublished data). Transgenic maize plants with this promoter are being obtained and should help to evaluate the hypothesis that localised expression of transgenes is a good strategy to obtain $\mathrm{Al}$ resistance.

\section{Transgenic plants with increased $O A$ efflux and soil microbiota}

Root exudates have great impact on soil microbiota, which are key components for plant nutrient supply. For example, the rhizosecretion of glutamate, aspartate and dicar- 
boxylic acids attracts Bradyrhizobium japonicum to soybean roots (Barbour et al., 1991), while flavonoids released by several legume species induce nod genes in rhizobia, with an important role in nodulation (Peters et al., 1986). Transgenic plants exudates have been shown to change root-associated bacterial populations, as observed by Oger et al. (2000), who found that the opine-utilizing bacteria population increased in soil cultivated with transgenic Lotus corniculatus that exudes opines.

The impact of the release of OA from transgenic plants has only recently been addressed. It might be expected that bacteria that use organic acids could have a selective advantage in soils where transgenic plants with increased efflux of OA are being grown. Tesfaye et al. (2003) evaluated the diversity of rhizobacteria and soil nutrient availability in soils cultivated with transgenic alfalfa plants expressing the $n e M D H$ gene, using a non-transformed plant as control. Total DNA was extracted from soil samples and sequences from the $16 \mathrm{~S}$ ribossomal DNA was used to infer the relative abundance of bacteria. Significant differences between soil planted with transgenic and non-transformed plants were found for a few bacterial groups. Untransformed alfalfa had higher numbers of flexibacter and unknown bacteria, while transgenic alfalfa had higher diversity of gram-positive bacteria with high $\mathrm{G}+\mathrm{C}$ DNA content, nitrospira, and fibrobacterium/acidobacterium. This finding is in line with the fact that the rhizosphere soil associated with transgenic alfalfa roots had bacteria with a higher array of substrate utilisation and greater functional diversity. Furthermore, Tesfaye et al. (2003) observed that several mineral nutrients like $\mathrm{P}, \mathrm{K}, \mathrm{Mn}, \mathrm{Cu}$, and $\mathrm{Zn}$ were more highly available in the rhizosphere soil of transformed plants, showing that these plants have a great potential to mobilise soil nutrients.

These specific effects of transgenic plants on soil microbiota are not surprising if we consider that common agricultural practices such as crop rotation and use of fertilisers are anthropogenic activities that also cause significant changes in microbial biomass and community structure (O’Donnell et al., 2001). Although these changes are well known, knowledge of their relationship to soil processes is scarce (O'Donnell et al., 2001) and further studies on rhizosphere ecology with other transgenic plants should contribute to a better understanding of this subject.

Acknowledgements: The financial support provided by FAPESP, through a postdoctoral fellowship to EDM (04/04821-0), and a grant to MM (04/05131-7), is gratefully acknowledged.

\section{REFERENCES}

Andrade LRM, Ikeda M, Ishizuka J (1997) Stimulation of organic acid excretion by roots of aluminum-tolerant and aluminum-sensitive wheat varieties under aluminum stress. Braz. J. Plant Physiol. 9:27-34.

Anoop VM, Basu U, McCammon MT, McAlister-Henn L, Taylor GJ (2003) Modulation of citrate metabolism alters aluminum tolerance in yeast and transgenic canola overexpressing a mitochondrial citrate synthase. Plant Physiol. 132:2205-2217.

Barbier-Brygoo H, Vinauger M, Colcombet J, Ephritikhine G, Frachisse J-F, Christophe M (2000) Anion channels in higher plants: functional characterization, molecular structure and physiological role. Biochim. Biophys. Acta 1465:199-218.

Barbour WM, Hatttermann DR, Stacey G (1991) Chemotaxis of Bradyrhizobium japonicum to soybean exudates. Appl. Environ. Microbiol. 57:2635-2639.

Barceló J, Poschenrieder C (2002) Fast root growth responses, root exudates, and internal detoxification as clues to the mechanisms of aluminium toxicity and resistance: a review. Environ. Exp. Bot. 48:75-92.

Basu U, Godbold D, Taylor GJ (1994) Aluminum resistance in Triticum aestivum L. associated with enhanced exudation of malate. J. Plant Physiol. 144:747-753.

Basu U, Basu A, Taylor GJ (1994) Differential exudation of polypeptides by roots of aluminum-resistant and aluminum-sensitive cultivars of Triticum aestivum L. in response to aluminum stress. Plant Physiol. 106: $151-158$.

Basu U, Good AG, Taylor GJ (2001) Transgenic Brassica napus plants overexpressing aluminium-induced mitochondrial manganese superoxide dismutase cDNA are resistant to aluminium. Plant Cell Environ. 24: 1269-1278.

Cocker KM, Evans DE, Hodson MJ (1998) The amelioration of aluminium toxicity by silicon in wheat (Triticum aestivum L.): malate exudation as evidence form an in planta mechanism? Planta 204:318-323.

de la Fuente JM, Ramirez-Rodriguez V, Cabrera-Ponce JL, Herrera-Estrella L (1997) Aluminum tolerance in transgenic plants by alteration in citrate synthesis. Science 275:1566-1568.

Delhaize E, Hebb DM, Ryan PR (2001) Expression of a Pseudomonas aeruginosa citrate synthase gene in tobacco is not associated with either enhanced citrate accumulation or efflux. Plant Physiol. 125:2059-2067.

Delhaize E, Ryan PR (1995) Aluminum toxicity and tolerance in plants. Plant Physiol. 107:315-321.

Delhaize E, Ryan PR, Hebb DM, Yamamoto Y, Sasaki T, Matsumoto H (2004) Engineering high-level aluminum tolerance in barley with the ALMT1 gene. Proc. Natl Acad. Sci. USA 101:15249-15254.

Delhaize E, Ryan PR, Hocking PJ, Richardson AE (2003) Effects of altered citrate synthase and isocitrate dehydrogenase expression on internal citrate concentrations and citrate efflux from tobacco (Nicotiana tabacum L.) roots. Plant Soil 248:137-144. 
Delhaize E, Ryan PR, Randall PJ (1993) Aluminum tolerance in wheat (Triticum aestivum L.). II. Aluminum-stimulated excretion of malic acid from root apices. Plant Physiol. 103:695-702.

Doering DS (2004) Designing genes: How can genetic engineering serve U.S. midwestern agricultural sustainability? World Resources Institute. http://pubs.wri.org/pubs_pdf. cfm?PubID $=3898$

Ermolayev V, Weschke W, Manteuffel R (2003) Comparison of Al-induced gene expression in sensitive and tolerant soybean cultivars. J. Exp. Bot. 54:2745-2756.

Ezaki B, Gardner RC, Ezaki Y, Matsumoto H (2000) Expression of aluminum-induced genes in transgenic Arabidopsis plants can ameliorate aluminum stress and/ or oxidative stress. Plant Physiol. 122:657-665.

Ezaki B, Katsuhara M, Kawamura M, Matsumoto H (2001) Different mechanisms of four aluminum (Al)-resistant transgenes for Al toxicity in Arabidopsis. Plant Physiol. 127:918-927.

Ezaki B, Suzuki M, Motoda H, Kawamura M, Nakashima S, Matsumoto H (2004) Mechanism of gene expression of Arabidopsis glutathione S-transferase, AtGST1, and AtGST11 in response to aluminum stress. Plant Physiol. 134:1672-1682.

Foy CD (1984) Physiological effects of hydrogen, aluminium and manganese toxicities in acid soil. In: Adams F (ed), Soil acidity and liming, pp.57-97. Agronomy Monograph 12, Second Edition. ASA, CSSA, and SSSA, Madison, USA.

Foy CD, Lee EH, Coradetti CA, Taylor GJ (1990) Organic acids related to differential aluminium tolerance in wheat (Triticum aestivum) cultivars. In: van Beusichem ML (ed), Plant nutrition - physiology and applications, pp. 381-389. Kluwer Academic Publishers, Dordrecht, The Netherlands.

Foy CD, Lee EH, Wilding SB (1987) Differential aluminum tolerances of two barley cultivars related to organic acids in their roots. J. Plant Nutr. 10:1089-1101.

Gaume A, Mächler F, Frossard E (2001) Aluminum resistance in two cultivars of Zea mays L.: Root exudation of organic acids and influence of phosphorus nutrition. Plant Soil 234:73-81.

Haake V, Cook D, Riechmann JL, Pineda O, Thomashow MF, Zhang JZ (2002) Transcription factor CBF4 is a regulator of drought adaptation in Arabidopsis. Plant Physiol. 130:639-648.

Hayes JE, Ma JF (2003) Al-induced efflux of organic acid anions is poorly associated with internal organic acid metabolism in triticale roots. J. Exp. Bot. 54:1753-1759.

Haynes RJ (1990) Active ion uptake and maintenance of cation-anion balance: A critical examination of their role in regulating rhizosphere $\mathrm{pH}$. Plant Soil 126:247-264.

Hoekenga OA, Vision TJ, Shaff JE, Monforte AJ, Lee GP, Howell SH, Kochian LV (2003) Identification and characterization of aluminum tolerance loci in Arabidopsis (Landsberg erecta $\times$ Columbia) by quantitative trait locus mapping. A physiologically simple but genetically complex trait. Plant Physiol. 132:936-948.
Hoffland E, van den Boogaard R, Nelemans JA, Findenegg $\mathrm{G}$ (1992) Biosynthesis and root exudation of citric and malic acids in phosphate-starved rape plants. New Phytol. 122:675-680.

Johnson JF, Allan DL, Vance CP (1994) Phosphorus stressinduced proteoid roots show altered metabolism in Lupinus albus. Plant Physiol. 104:657-665.

Johnson JF, Allan DL, Vance CP, Weiblen G (1996) Root carbon dioxide fixation by phosphorus-deficient Lupinus albus. Contribution to organic acid exudation by proteoid roots. Plant Physiol. 112:19-30.

Jones DL (1998) Organic acids in the rhizosphere - a critical review. Plant Soil 205:25-44.

Jones DL, Darrah PR (1996) Re-sorption of organic components by roots of Zea mays L. and its consequences in the rhizosphere. III. Characteristics of sugar influx and efflux. Plant Soil 178:153-160.

Jorge RA, Arruda P (1997) Aluminum-induced organic acids exudation by roots of an Al-tolerant tropical maize variety. Phytochemistry 45:675-681.

Jorge RA, Menossi M, Arruda P (2001) Probing the role of calmodulin in Al toxicity in maize. Phytochemistry 58: 415-422.

Keltjens WG (1987) Nitrogen source and aluminum toxicity of two sorghum genotypes differing in aluminum susceptibility. J. Plant Nutr. 10:841-856.

Keltjens WG, van Ulden PRS (1987) Effects of Al on nitrogen $\left(\mathrm{NH}_{4}^{+}\right.$and $\left.\mathrm{NO}_{3}^{-}\right)$uptake, nitrate reductase activity and proton release in two sorghum cultivars differing in $\mathrm{Al}$ tolerance. Plant Soil 104:227-234.

Kidd PS, Llugany M, Poschenrieder C, Gunse B, Barceló J (2001) The role of root exudates in aluminium resistance an silicon-induced amelioration of aluminium toxicity in three varieties of maize (Zea mays L.). J. Exp. Bot. 52: 1339-1352.

Kochian LV (1995) Cellular mechanisms of aluminum toxicity and resistance in plants. Annu. Rev. Plant Physiol. Plant Mol. Biol. 46:237-260.

Kochian LV, Hoekenga OA, Piñeros MA (2004) How do crop plants tolerate acid soils? Mechanisms of aluminum tolerance and phosphorus efficiency. Annu. Rev. Plant Biol. 55:459-493.

Kollmeier M, Dietrich P, Bauer CS, Horst WJ, Hedrich R (2001) Aluminum activates a citrate-permeable anion channel in the aluminum-sensitive zone of the maize root apex. A comparison between an aluminum-sensitive and an aluminum-resistant cultivar. Plant Physiol. 126: 397-410.

Koyama H, Kawamura A, Kihara T, Hara T, Takita E, Shibata D (2000). Overexpression of mitochondrial citrate synthase in Arabidopsis thaliana improved growth on a phosphorus-limited soil. Plant Cell Physiol. 41: 1030-1037.

Lee JT, Prasad V, Yang PT, Wu JF, Ho THD, Charng YY, Chan MT (2003) Expression of Arabidopsis CBF1 regulated by an $\mathrm{ABA} /$ stress inducible promoter in transgenic tomato confers stress tolerance without affecting yield. Plant Cell Environ. 26:1181-1190. 
Li XF, Ma JF, Matsumoto H (2000) Pattern of aluminum-induced secretion of organic acids differs between rye and wheat. Plant Physiol. 123:1537-1543.

Li XF, Ma JF, Matsumoto H (2002) Aluminum-induced secretion of both citrate and malate in rye. Plant Soil 242: 235-243.

López-Bucio J, de la Vega MO, Guevara-García A., HerreraEstrella L (2000) Enhanced phosphorus uptake in transgenic tobacco plants that overproduce citrate. Nature Biotech. 18:450-453.

Ma JF (2000) Role of organic acids in detoxification of aluminum in higher plants. Plant Cell Physiol. 41:383-390.

Ma JF, Hiradate S (2000) Form of aluminium for uptake and translocation in buckwheat (Fagopyrum esculentum Moench.). Planta 211:355-360.

Ma JF, Hiradate S, Matsumoto H (1998) High aluminum resistance in buckwheat. II. Oxalic acid detoxifies aluminum internally. Plant Physiol. 117:753-759.

Ma JF, Hiradate S, Nomoto K, Iwashita T, Matsumoto H (1997c) Internal detoxification mechanism of $\mathrm{Al}$ in hydrangea (Identification of $\mathrm{Al}$ form in the leaves). Plant Physiol. 113:1033-1039.

Ma JF, Ryan PR, Delhaize E (2001) Aluminium tolerance in plants and the complexing role of organic acids. Trends Plant Sci. 6:273-278.

Ma JF, Shen R, Zhao Z, Wissuwa M, Takeuchi Y, Ebitani T, Yano M (2002) Response of rice to Al stress and identification of quantitative trait loci for Al tolerance. Plant Cell Physiol. 43:652-659.

Ma JF, Taketa S, Yang ZM (2000) Aluminum tolerance genes on the short arm of chromosome 3R are linked to organic acid release in triticale. Plant Physiol. 122:687-694.

Ma JF, Zheng SJ, Hiradate S, Matsumoto H (1997a) Detoxifying aluminum with buckwheat. Nature 390: 569-570.

Ma JF, Zheng SJ, Matsumoto H (1997b) Specific secretion of citric acid induced by Al stress in Cassia tora L. Plant Cell Physiol. 38:1019-1025.

Ma Z, Miyasaka SC (1998) Oxalate exudation by taro in response to Al. Plant Physiol. 118:861-865.

Mariano ED (2003) Citrate exudation by maize roots, a possible mechanism of resistance to aluminium. Wageningen, Wageningen University. $\mathrm{PhD}$ thesis.

Mariano ED, Keltjens WG (2003) Evaluating the role citrate exudation as a mechanism of aluminium resistance in maize genotypes. Plant Soil 256:469-479.

Mariano ED, Keltjens WG (2004) Variation for aluminum resistance among maize genotypes evaluated with three screening methods. Commun. Soil Sci. Plant Anal. 35: 2617-2637.

Marschner H (1995) Mineral nutrition of higher plants. $2^{\text {nd }}$ edn. Academic Press, London.

Menosso OG, Costa JA, Anghinoni I, Bohnen H (2001) Crescimento radicular e produção de ácidos orgânicos em cultivares de soja com diferentes tolerâncias ao alumínio. Pesq. Agrop. Bras. 36:1339-1345.

Miyasaka SC, Butta JG, Howell RK, Foy CD (1991) Mechanism of aluminium tolerance in snapbeans. Root exudation of citric acid. Plant Physiol. 96:737-743.

Nagata T, Hayatsu M, Kosuge N (1992) Identification of aluminium in tea leaves by ${ }^{27} \mathrm{Al}$ NMR. Phytochemistry 31:1215-1218.

Naik MS, Nicholas DJD (1986) Malate metabolism and its relation to nitrate assimilation in plants. Phytochemistry 25:571-576.

O`Donnell AG, Seasman M, Macrae A, Waite I, Davies JT (2001) Plants and fertilisers as drivers of change in microbial community structure and function in soils. Plant Soil 232:135-145.

Oger P, Mansouri H, Dessaux Y (2000) Effect of crop rotation and soil cover on alteration of the soil microflora generated by the culture of transgenic plants producing opines. Mol. Ecol. 9:881-890.

Pellet DM, Grunes DL, Kochian LV (1995) Organic acid exudation as an aluminum-tolerance mechanism in maize (Zea mays L.). Planta 196:788-795.

Pellet DM, Papernick LA, Kochian LV (1996) Multiple aluminum-resistance mechanisms in wheat. Plant Physiol. 112:591-597.

Peters NK, Frost JW, Long SR (1986) A plant flavone, luteolin, induces expression of Rhizobium meliloti nodulation genes. Science 233:977-980.

Piñeros MA, Kochian LV (2001) A patch clamp study on the physiology of aluminum toxicity and aluminum tolerance in maize: identification and characterization of $\mathrm{Al}^{3+}$ induced anion channels. Plant Physiol. 125:292-305.

Piñeros MA, Magalhães JV, Alves VMC, Kochian LV (2002) The physiology and biophysics of an aluminum tolerance mechanism based on root citrate exudation in maize. Plant Physiol. 129: 1194-1206.

Piñeros MA, Shaff JE, Manslank HS, Alves VMC, Kochian LV (2005) Aluminum resistance in maize cannot be solely explained by root organic acid exudation. A comparative physiological study. Plant Physiol. 137:231-241.

Rengel Z (2002) Genetic control of root exudation. Plant Soil 245:59-70.

Ryan PR, Delhaize E, Jones DL (2001) Function and mechanism of organic anion exudation from plant roots. Annu. Rev. Plant Physiol. Mol. Biol. 52:527-560.

Ryan PR, Delhaize E, Randall PJ (1995) Characterisation of Al-stimulated efflux of malate from the apices of Altolerant wheat roots. Planta 196:103-110.

Ryan PR, Skerrett M, Findlay GP, Delhaize E, Tyerman SD (1997) Aluminum activates an anion channel in the apical cells of wheat roots. Proc. Natl Acad. Sci. USA 94: 6547-6552.

Saber N, Abdel-Moneim A, Barakat S (1999) Role of organic acids in sunflower tolerance to heavy metals. Biol. Plant. 42:65-73.

Sasaki T, Yamamoto Y, Ezaki B, Katsuhara M, Ahn SJ, Ryan PR, Delhaize E, Matsumoto H (2004) A wheat gene encoding an aluminum-activated malate transporter. Plant J. 37:645-653.

Shen R, Ma JF, Kyo M, Iwashita T (2002) Compartmentation of aluminium in leaves of an Al-accumulator, Fagopyrum esculentum Moench. Planta 215:394-398. 
Silva IR, Smyth TJ, Raper CD, Carter TE, Rufty TW (2001) Differential aluminum tolerance in soybean: an evaluation of the role of organic acids. Physiol. Plant. 112:200-210.

Sivaguru M, Ezaki B, He ZH, Tong HY, Osawa H, Baluska F, Volkmann D, Matsumoto H (2003) Aluminum-induced gene expression and protein localization of a cell wallassociated receptor kinase in Arabidopsis. Plant Physiol. 132:2256-2266.

Taiz L, Zeiger E (2002) Plant physiology. $3^{\text {rd }}$ edn. Sinauer Associates Inc., Sunderland.

Taylor GJ (1991) Current views of the aluminum stress response; the physiological basis of tolerance. Curr. Top. Plant Biochem. Physiol. 10:57-93.

Tesfaye M, Dufault N, Dornbusch MR, Allan DL, Vance CP, Samac DA (2003) Influence of enhanced malate dehydrogenase expression by alfalfa on diversity of rhizobacteria and soil nutrient availability. Soil Biol. Biochem. 35:1103-1113.

Tesfaye M, Temple SJ, Allan DL, Vance CP, Samac DA (2001) Overexpression of malate dehydrogenase in transgenic alfalfa enhances organic acid synthesis and confers tolerance to aluminum. Plant Physiol. 127: 1836-1844.

Wang Y, Stass A., Horst WJ (2004) Apoplastic binding of aluminum is involved in silicon-induced amelioration of aluminum toxicity in maize. Plant Physiol. 136: 3762-3770.

Watanabe T, Osaki M, Yoshihara T, Tadano T (1998) Distribution and chemical speciation of aluminum in the Al accumulator plant, Melastoma malabathricum L. Plant Soil 201:165-173.
Wenzl P, Patino GM, Chaves AL, Mayer JE, Rao IM (2001) The high level of aluminum resistance in signalgrass is not associated with known mechanisms of external aluminum detoxification in root apices. Plant Physiol. 125:1473-1484.

Yang Z, Yang H, Wang J, Wang Y (2004) Aluminum regulation of citrate metabolism for Al-induced citrate efflux in the roots of Cassia tora L. Plant Sci. 166: 1589-1594.

Yang ZM, Nian H, Sivaguru M, Tanakamaru S, Matsumoto $\mathrm{H}$ (2001) Characterization of aluminium-induced citrate secretion in aluminium-tolerant soybean (Glycine max) plants. Physiol. Plant. 113:64-71.

Yang ZM, Sivaguru M, Horst W, Matsumoto H (2000) Aluminum tolerance is achieved by exudation of citric acid from roots of soybean (Glycine max). Physiol. Plant. 110:72-77.

Zhang W, Ryan PR, Tyerman SD (2001) Malate-permeable channels and cation channels activated by aluminum in the apical cells of wheat roots. Plant Physiol. 125: 1459-1472.

Zhao Z, Ma JF, Sato K, Takeda K (2003) Differential Al resistance and citrate secretion in barley (Hordeum vulgare L.). Planta 217:794-800.

Zheng SJ, Ma JF, Matsumoto H (1998a) Continuous secretion of organic acids is related to aluminum resistance during relatively long-term exposure to aluminum stress. Physiol. Plant. 103:209-214.

Zheng SJ, Ma JF, Matsumoto H (1998b) High aluminum resistance in buckwheat. I. Al-induced specific secretion of oxalic acid from root tips. Plant Physiol. 117:745-751. 